\title{
Application of Rice Straw Compost with Different Bioactivators on the Growth and Yield of Rice Plant
}

\author{
Yunita Barus \\ Assessment Institute for Agricultural Technology (AIAT) of Lampung, Jl. Z.A. Pagar Alam No. 1A, \\ Rajabasa 35144, Indonesia. Telp.(0721) 781776, e-mail: yunita_0106@yahoo.co.id
}

Received 4 December 2009 / accepted 20 July 2011

\begin{abstract}
Turnover of organic matters to the soil can increase the efficiency of chemical fertilizers, improve the plant growth and sustain the environment. Field experiment was carried out in the Buyut Udik Village, Gunung Sugih District, Central Lampung from May to August 2009. Rice straw was composted by three kinds of decomposer (bioactivator A, B, and C). Rice straw compost $\left(2 \mathrm{Mg} \mathrm{ha}^{-1}\right)$ was applied to the paddy-field soil that was planted by rice (Oryza sativa) of Ciherang Variety. The experiment was arranged in a randomized block design with three replicates. The results showed that application of rice straw compost reduced the numbers of empty grain per tiller compared to control (without compost) in which control had the highest percentage of empty grain (15.9\%). The application of rice straw compost that was decomposed by bioactivator A gave the highest numbers of grain per panicle and yield per plot as followed 162.5 seed and $33 \mathrm{~kg} \mathrm{plot}^{-1}$, respectively. Application of various rice straw composts that were decomposed by three kinds of bioactivator increased the rice grain up to $13-26 \%$ compared to control.
\end{abstract}

Keywords: Bioactivator, rice straw compost, rice yield

\section{INTRODUCTION}

Intensive farming systems that are applied so far are marked by the use of chemical fertilizers (especially nitrogen) and pesticides in large quantities, so that in long periods of time it will change the physical and chemical properties of soil and reduces the land productivity (Djamhari 2002; Las et al. 2002). One indicator of declining the soil fertility is low level of soil organic matter. Karama et al. (1990) reported that from 30 locations of the paddy-field soil in Indonesia that was taken randomly, $68 \%$ had low soil organic matter content $(<1.5 \%)$ and only $9 \%$ had high organic matter content (> $2 \%)$.

Application of organic matter play a critical role in both of short-term nutrient availability and longterm maintenance of soil organic matter in farming systems in tropical agro ecosystems (Palm et al. 2001). Junaedi (2008) reported that application of rice straw compost of $10 \mathrm{Mg} \mathrm{ha}^{-1}$ reduced soil density and improved soil permeability. The function of organic matter is as a glue for soil granular, so it will form and consolidate the soil aggregate, therefore

J Trop Soils, Vol. 17, No. 1, 2012: 25-29 ISSN 0852-257X aeration, permeability and infiltration of the soil become more better (Stevenson 1994).

Many kinds of organic fertilizers can be made from local materials, such as crop removal, rice straw, manure, etc. Rice straw is very potential as the organic fertilizer raw material that is available during the rice harvest. The conten of nutrients in rice straw are potassium $1.2-1.7 \%, \mathrm{~N}(0.5-0.8 \%)$, $\mathrm{P}(0.07-0.12 \%)$, and S (0.05-0.10\%) (Dobermann and Fairhurst 2000). According to Basyir and Suyamto (1996), application $5.0 \mathrm{Mg} \mathrm{ha}^{-1}$ rice straw could save the use of $\mathrm{KCl}$ fertilizer equal to $100 \mathrm{~kg}$ $\mathrm{ha}^{-1}$.

Application of rice straw compost and manure $5 \mathrm{Mg} \mathrm{ha}^{-1}$ could increase the $\mathrm{N}$ absorption and the content of leaf chlorophyll a and b (Iqbal 2008). Furthermore, Pramono (2004) reported that the application of organic fertilizer could increase the yield components like the number of stem, the weight of 1,000 grains and the grain weight per plots, also it could reduce the amount of chemical fertilizer especially potassium.

Rice straw could be applied directly into soil or as compost in order to mineralize nutrient to be available for the crop production. Composting is a biological method to decompose raw organic materials under controlled conditions where it can be handled, stored and applied to the soil to supply 
essential nutrients without adversely affecting the environment (Cooper and Golueke 1977). The results of research by Gunarto et al. (2002), the levels of $\mathrm{P}, \mathrm{K}, \mathrm{Na}, \mathrm{Ca}, \mathrm{Mg}, \mathrm{Mn}$, and $\mathrm{Cu}$ nutrients of composted straw west higher than raw straw. The research that was airmed to study the form of straw accordance to the absorption of nutriens by paddy was carried out by Hardiatmi (2006), the results that application of composted straw increased $\mathrm{N}$ and $\mathrm{K}$ uptake than dry biomass and ash.

To accelerate the composting process of rice straw, many kind of decomposers (bioactivator) can be applied. Various kinds of decomposer are produced by the research institute and partly are produced by private company. Husen et al. (2007) reported that bioactivators or commercial biofertilizers at the market (agricultural shops) in Bandung District, West Java, contain various strain of bacteria from genus Rhizobium, Azotobacter, Bacillus, Lactobacillus Azospirillum, Aspergillus, Actinomycetes, Lactobacilius, or Pseudomonas that has been mixed together with Actinomycetes or fungi such as Streptomyces or Aspergillus. There is a close relationship between soil quality and soil microbial activity in the soil. Saraswati (2007) reported that microbial community plays an important roles, such as transforming soil nutrient, managing nutrient availability, affecting plant growth through the ability to nitrogen fixation, to $\mathrm{P}$ solubilize, and to produce plant growth promoting hormone.

The objective of this study was to compare the effect of the application rice straw composts that were decomposed by several kinds of bioactivators on the growth and yield of rice plant.

\section{MATERIALS AND METHODS}

\section{Study Site}

This research was carried out in Buyut Udik Village, Gunung Sugih District, Central Lampung Regency from May to August 2009.

\section{Rice Straw Composting}

This activity consisted of two steps, that were: I. Composting the rice straw with three kinds of decomposer (bioactivator) which were Bioactivator A (Promi) (consists of several microorganisms such as Aspergillus sp., Trichoderma harzianum DT 38, Trichoderma harzianum DT 39, etc.); Bioctivator B (EM 4) (consists of Lactobacillus sp., photosynthetic bacteria, Streptomyces, Actinomycetes, and Yeast); and Bioactivator C (BeKa) (consists of Azospirillum, Aspergillus,
Actinomycetes, Lactobacilius, Pseudomonas, and Yeast). The composting process was one month. Chemical properties of compost was analysed immediately after the process ended at Soil science Laboratory, Faculty of Agriculture, University of Lampung.

\section{Field Experiment}

Three kinds of rice straw compost above which were decomposed by bioactivator $\mathrm{A}, \mathrm{B}$, and $\mathrm{C}\left(2 \mathrm{Mg} \mathrm{ha}^{-1}\right)$ and control ( $\mathrm{D}=$ without compost $)$ were applied to the paddy soil. A rice plant, Ciherang (Oryza sativa), was transplanted into paddy field. The basal chemical fertilizers applied before transplanting were: $250 \mathrm{~kg} \mathrm{ha}^{-1}$ urea and 200 $\mathrm{kg} \mathrm{ha}^{-1}$ NPK fertilizers Ponska. The size of plots was $8 \mathrm{~m} \times 5 \mathrm{~m}$. The experiment was arranged in arandomized block design with three replicates.

Plant growth parameters such as plant height, tiller number, and tiller length were measured as well as parameters such as grain number panicle ${ }^{-1}$. 1000 grain weight, empty grain were also recorded properly.

\section{Statistical Analysis}

All data were statistically analyzed by analysis of variance (ANOVA). Comparisons among means were made using the least significant difference (LSD) test calculated at $\mathrm{P}<0.05$.

\section{RESULTS AND DISCUSSION}

The soil chemical properties before the application of compost can be seen in Table 1. Soil pH and soil organic carbon were 4.73 and $1.09 \%$, respectively, that in low category.

Soil fertility was low, due to the value of soil $\mathrm{pH}$, as well as organic- $\mathrm{C}$ and soil nutrients content $(\mathrm{N}, \mathrm{K}$, etc), and cation exchanged capacity (CEC) were also low.

Nutrient contents and $\mathrm{pH}$ of compost with different kinds of bioactivator are presented in the Table 2. The level of organic-C was high enough that was between $16.37-20.02 \%$, and total $\mathrm{N}$ was $0.66-0.73 \%$. Although the content of the soil organic matter was very low that was $1-5 \%$ from soil mineral, but its effects on the soil physical, chemical and biological properties were very significant (Stevenson 1994).

Moreover, application of composts (A, B, and C) were contributed to $\mathrm{P}$ and $\mathrm{K}$ nutrients, where the highest level of potassium $(0,69 \%)$ was examined at compost A. Decomposition of organic material produces the simpler organic compound and 
Table 1. Soil chemical properties in the research location (Buyut Udik Village, Gunung Sugih District, Lampung Tengah Regency).

\begin{tabular}{lc}
\hline Soil properties & Values \\
\hline $\left.\mathrm{N}(\%) \mathrm{Kejdahl}^{-1}\right)$ & 0.10 \\
$\mathrm{P}-\mathrm{Bray}\left(\mathrm{mg} \mathrm{kg}^{-1}\right)$ & 6.61 \\
Organic-C $(\%)$ & 1.09 \\
$\mathrm{pH} \mathrm{H} \mathrm{H}_{2} \mathrm{O}(1: 2.5)$ & 4.73 \\
$\mathrm{pH} \mathrm{KCl}(1: 2.5)$ & 3.85 \\
$\mathrm{Al}-\mathrm{dd}\left(\mathrm{cmol} \mathrm{kg}^{-1}\right)$ & 0.30 \\
$\mathrm{H}-\mathrm{dd}\left(\mathrm{cmol} \mathrm{kg}^{-1}\right)$ & 0.10 \\
$\mathrm{~K}\left(\mathrm{cmol} \mathrm{kg}^{-1}\right)$ & 0.14 \\
$\mathrm{Na}\left(\mathrm{cmol} \mathrm{kg}^{-1}\right)$ & 0.08 \\
$\mathrm{Ca}\left(\mathrm{cmol} \mathrm{kg}^{-1}\right)$ & 2.81 \\
$\mathrm{Mg}\left(\mathrm{cmol} \mathrm{kg}^{-1}\right)$ & 1.13 \\
$\mathrm{CEC}\left(\mathrm{cmol} \mathrm{kg}^{-1}\right)$ & 8.92 \\
$\mathrm{Base} \mathrm{Saturation}(\%)$ & 46.63 \\
\hline
\end{tabular}

the unstable inorganic compound, and also it is the source of various crop nutrition, especially nitrogen and phosphor, as well as it can increase the soil pH and CEC (Ismunadji et al. 1991). Mahmoud et al. (2009) reported that $\mathrm{P}$ availability significantly increased by application of rice straw compost compared to water residuals treatment. In addition, the results also showed the soil salinity was reduced by the application of rice straw compost.

Effect of composts was not significantly on plant height and number of tiller, but numbers of grain tiller ${ }^{-1}$ with application of compost were significantly higher than control (Table 3 ). Although the yields of grain plot $^{-1}$ were not significantly different but descriptively it was higher than control. The highest yield was in the compost A treatment $\left(33.0 \mathrm{~kg} \mathrm{plot}^{-1}\right)$. This phenomenon might be caused by rice straw compost contained some elements of the nutrients that were needed for the crop growth especially nitrogen and it could increase the $\mathrm{N}$ absorption and the content of chlorophyll a and b of the rice crop (Iqbal 2008). Arafah and Sirappa (2003) also reported that application of rice straw compost $2 \mathrm{Mg} \mathrm{ha}^{-1}$ that was combined with NPK fertilizer increased significantly the number of tiller and tended to increase the grain yield.

Application of compost reduced the numbers of empty grain per stem, while the treatment without compost (D) had highest percentage of empty grain $(15,9 \%)$ (Figure 1$)$. The highest numbers of grain were at compost A treatment

Table 2. Chemical properties of rice straw composts.

\begin{tabular}{lccc}
\hline Chemical properties & Compost A & Compost B & Compost C \\
\hline $\mathrm{pH}\left(\mathrm{H}_{2} \mathrm{O}\right)$ & 8.97 & 8.47 & 8.67 \\
Organic-C $(\%)$ & 20.02 & 16.37 & 17.77 \\
Total-N $(\%)$ & 0.73 & 0.66 & 0.73 \\
$\mathrm{C} / \mathrm{N}$ & 27.42 & 24.80 & 23.69 \\
Total-P $(\%)$ & 0.12 & 0.11 & 0.12 \\
Total-K $(\%)$ & 0.69 & 0.40 & 0.63 \\
\hline
\end{tabular}

Table 3. The Effects of rice straw composts on vegetative growth and yield components of paddy at dry season year 2009 .

\begin{tabular}{cccccccc}
\hline $\begin{array}{c}\text { Rice straw } \\
\text { compost }\end{array}$ & $\begin{array}{c}\text { Plant height } \\
(\mathrm{cm})\end{array}$ & $\begin{array}{c}\text { Tiller } \\
\text { number }\end{array}$ & $\begin{array}{c}\text { Tiller length } \\
(\mathrm{cm})\end{array}$ & $\begin{array}{l}\text { Grain } \\
\text { number } \\
\text { panicle }^{-1}\end{array}$ & $\begin{array}{c}\text { Empty } \\
\text { grain }(\%)\end{array}$ & $\begin{array}{c}1,000 \text { grains } \\
\text { weight }\end{array}$ & $\begin{array}{c}\text { Grain weight } \\
\text { plot }^{-1} \\
(\mathrm{~kg})\end{array}$ \\
\hline $\mathrm{A}$ & $95.75 \mathrm{a}$ & $11.05 \mathrm{a}$ & $24.20 \mathrm{a}$ & $162.5 \mathrm{a}$ & $8.8 \mathrm{~b}$ & $30.92 \mathrm{a}$ & $33.0 \mathrm{a}$ \\
$\mathrm{B}$ & $92.05 \mathrm{a}$ & $10.83 \mathrm{a}$ & $23.75 \mathrm{a}$ & $152.1 \mathrm{a}$ & $10.2 \mathrm{ab}$ & $29.33 \mathrm{a}$ & $31.3 \mathrm{a}$ \\
$\mathrm{C}$ & $92.60 \mathrm{a}$ & $10.53 \mathrm{a}$ & $23.35 \mathrm{a}$ & $150.8 \mathrm{a}$ & $10.9 \mathrm{ab}$ & $29.67 \mathrm{a}$ & $29.4 \mathrm{a}$ \\
$\begin{array}{c}\mathrm{D} \\
(\text { Control })\end{array}$ & $93.30 \mathrm{a}$ & $9.25 \mathrm{a}$ & $22.85 \mathrm{a}$ & $149.7 \mathrm{a}$ & $15.9 \mathrm{a}$ & $28.35 \mathrm{a}$ & $26.0 \mathrm{a}$ \\
\hline
\end{tabular}

Means followed by the same letter in the same coloumn are not significantly different according to LSD test $(\mathrm{P}>0.05)$. 


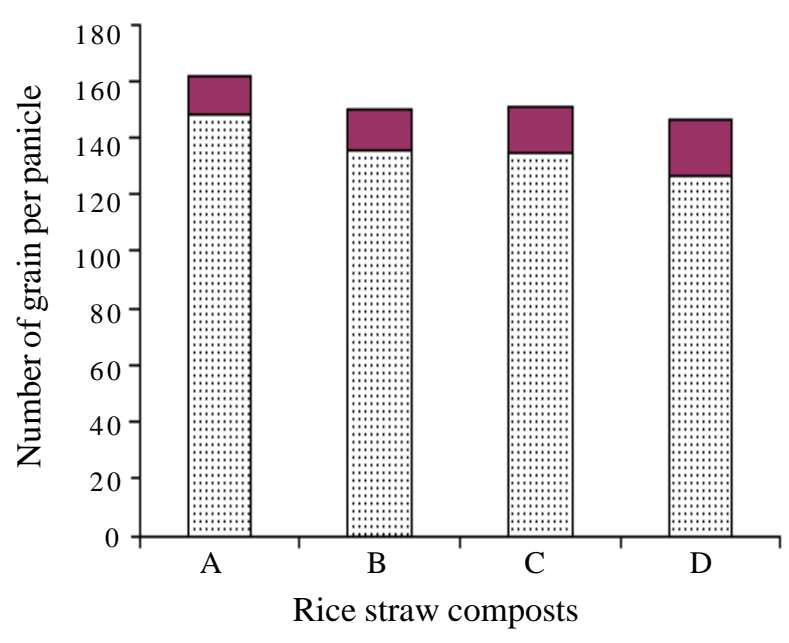

Figure 1. Effect of various rice straw composts on full (司) and empty grains ( $\square$ ).

(162.5). The increasing available nutrients from compost especially potassium (0.4-0.69\%) increased the obstinacy of plant, stimulated the growth root, resistance to the pest and plant disease, increased the percentage of empty grain and the weight of one thousand grains (Fairhurst and Witt 2005).

Weight of grain plot ${ }^{-1}$ increased by application of rice straw compost (Table 3 ). The highest yield was at application of compost A $(33.0 \mathrm{~kg})$, in which increasing more than $25 \%$ than that control. Iqbal (2008), reported that application of rice straw compost and $75 \%$ recommendation of $\mathrm{N}$ fertilizer had the highest contents of protein grain, where rice straw compost contributed to the availability of $\mathrm{P}$ and $\mathrm{K}$ nutrients which played a role in the synthesis of protein and carbohydrate. Amelioration in nutritional status, plant growth response and productivity as a result of compost addition to soil had been reported (Madejon et al. 2001)

\section{CONCLUSIONS}

Nutrient contents of compost: Organic-C (16.37 - 20.02\%), total-N (0.66 - 0.73\%), total-P $(0.11-0.12 \%)$, and total $\mathrm{K}(0.40-0.69 \%)$. Application of straw compost (A, B, and C) reduced the numbers of unfilled grain per stem, while the treatment without compost (D) had the highest percentage of unfilled grain (15.9\%). Application of rice straw compost A had the highest numbers of grain and weigth of grain rice per plot in which spective 162.5 and $33 \mathrm{~kg} \mathrm{plot}^{-1}$. Application of various rice straw compost increased yield per plot up to $13-26 \%$ than that without compost application control.

\section{REFFERENCES}

Arafah and MP Sirappa. 2003. Kajian penggunaan jerami dan pupuk N, P, dan K pada Lahan Sawah Irigasi. $J$ Ilmu Tanah Lingk 4 (1): 15-24 (in Indonesian).

Basyir A and Suyamto. 1996. Penelitian padi untuk mendukung pelestarian swasembada pangan. Pros. Sem. Apresiasi Hasil Penelitian Balittan Padi. Badan Litbang Pertanian. Buku I, pp. 146-170 (in Indonesian).

Cooper RC and GC Golueke. 1977. Public health aspects of on solid waste treatment. Compost Sci 18: 8-12.

Djamhari S. 2002. Pemasyarakatan teknologi budidaya pertanian organik di Desa Sembalun Lawang Nusa Tenggara Barat. J Sain Teknol Indon 5 (5): 195202 (in Indonesian).

Dobermann A. and T Fairhurst. 2000. Rice: Nutrient Disorders \& Nutrient Management. Potash \& Phosphate Institute (PPI), Potash \& Phosphate Institute of Canada (PPIC) and International Rice Research Institute (IRRI).

Fairhurst T and C Witt. 2005. Rice. A Practical Guide to Nutrient Management. Potash \& Phosphate Institute (PPI), Potash \& Phosphate Institute of Canada (PPIC), and International Rice Research Institute (IRRI).

Gunarto I, P Lestari, R Supadmo and AR Marzuki. 2002. Dekomposisi jerami padi, inokulasi Azospirillum dan pengaruhnya terhadap efisiensi penggunaan pupuk N pada padi sawah. J Penel Pert Tan Pangan 21 (1): 1-10 (in Indonesian).

Hardiatmi S. 2006. Kajian bentuk pemberian dan dosis jerami pada serapan $\mathrm{N}$ dan $\mathrm{K}$ serta hasil padi (Oryza sativa L.) Var. IR - 64. J Inovasi Pert 4 (2): 159171 (in Indonesian).

Husen E, RDM Simanungkalit, R Saraswati and Irawan. 2007. Characterization and quality assesment of Indonesian commercial biofertilizers. Indon J Agric Sci 8 (1): 31-38.

Iqbal A. 2008. Potensi kompos dan pupuk kandang untuk produksi padi organik pada tanah inceptisol. J Akta Agrosia 11 (1): 13-18, (in Indonesian).

Ismudaji M, S Partohardjono and AS Karama. 1991. Fosfor, dan Penggunaannya Dalam Bidang Pertanian. Balittan, Bogor, (in Indonesian).

Junaedi H. 2008. Pemanfaatan kompos jerami padi dan kapur guna memperbaiki permeabilitas tanah dan hasil kedelai musim tanam II. Prosiding Seminar Nasional Sains dan Teknologi-II 2008 Universitas Lampung, 17-18 November 2008, pp. VII 89- VII-94 (in Indonesian).

Karama AS, AR Marzuki and I Manwan. 1990. Penggunaan pupuk organik pada tanaman pangan. Prosiding Lokakarya Nasional Efisiensi Pupuk V. Cisarua 12-13 Nopember 1990, (in Indonesian).

Las I, HM Toha and A Gani. 2002. Panduan Teknis Pengelolaan Tanaman dan Sumberdaya Terpadu Padi Sawah Irigasi. Badan Litbang Pertanian, Departemen Pertanian, 37 p, (in Indonesian). 
Madejon E, R Lopez, JM Murillo and F Cabrera. 2001. Agricultural use of three (sugar-beet) vinasse composts: Effect on crops and chemical properties of Cambisol soil in the Gauadalquivir river valley (SW Spain). Agric Ecosyst Environ 84: 55-65.

Mahmoud E, M Ibrahim, P Robin, NA Corfini and M ElSaka. 2009. Rice Straw Composting and Its Effect on Soil Properties. Compost Sci Util 17 (3): 146-150.

Palm CA, CN Gachengo, RJ Delve, G Cadisch and KE Giller. 2001. Organic inputs for soil fertility management in tropical agroecosystems: application of an organic resource database. Agric Ecosyst Environ 83 (1-2): 27-42
Pramono J. 2004. Kajian Penggunaan Pupuk Organik pada Padi Sawah. J Agrosains 6 (1): 11-14, (in Indonesian).

Saraswati R. 2007. Roles of biofertilizers to increase fertilization efficiency in supporting sustainable soil productivity. $J$ Land Resources 1 (4): 51-55.

Stevenson FJ. 1994. Humus Chemistry: Genesis, Composition, Reactions. Second Edition. John Wiley and Sons, New York, 512 p. 